Western University

Scholarship@Western

Department of Economics Research Reports

Economics Working Papers Archive

1980

\title{
Towards a Protected Society: The Politicization of Economic Life
}

Thomas J. Courchene

Follow this and additional works at: https://ir.lib.uwo.ca/economicsresrpt

Part of the Economics Commons

Citation of this paper:

Courchene, Thomas J.. "Towards a Protected Society: The Politicization of Economic Life." Department of Economics Research Reports, 8014. London, ON: Department of Economics, University of Western Ontario (1980). 
ISSN :

$0318-725 x$

ISBN :

$0-7714-0190-6$

RESEARCH REPORT 8014

TOWARDS A PROTECTED SOCIETY:

THE POLITICIZATION OF ECONOMIC LIFE

by

Thomas J. Courchenet

July 1980

The Innis Memorial Lecture Canadian Economic Association Annual Meeting, June 1980 Montreal, Canada

A version similar to this will be published in the CJE in the fall issue. 
"The decline in vested interests peculiar to the period after Adam Smith was a tribute to the economic value of the Wealth of Nations, but the emergence of vested interests (i.e., the legitimate right to something for nothing) under capitalism has reduced the value of economic theory based on Adam Smith and increased the value of economic theory adapted to nationalism."

[Harold Adams Innis, 1946, p. 166] 


\section{Introduction}

"With only a few exceptions, the theme of contemporary social philosophy is anti-state, and the politicians are beginning to find that expression of such sentiments resonates well on the contemporary electorate" [Gordon, 1977, p. 112]. Scott Gordon's assessment is that this anti-state sentiment is rooted in the growth and spread of the view that what has been achieved by rapid public sector growth in respect of economic welfare and social justice is insufficient to justify the reduction in individual freedoms which the operation of the modern state entails. While not everyone would accept $\mathrm{Dr}$. Gordon's rationale, many observers would probably agree that government as a growth industry appears to have fallen on hard times. At the macro level, there is a growing realization that rapid expenditure growth, much of it money financed, helped fuel the fires of the current inflation. This perception, combined with the "tax revolt" or "Proposition 13" mentality has led, many legislators not only to seek to balance budgets but to do so primarily by paring expenditures. Even in terms of regulatory activity the tide might be viewed as receding. Deregulation has become the latest "buzzword" as the torrent of research in this area focuses on the many negative externalities that often accompany regulation. Friedman has generalized this concern over regulation into what he calls the invisible hand in politics as distinct from the invisible hand in economics):

In the political sphere individuals... who attempt to pursue the public interest as they view it are led by an invisible hand to further private interests which it is no part of their intention to promote [1977, p. 35]. 
Underlying all of this is a growing and influential political philosophy commonly referred to as neo-conservatism.

These developments notwithstanding, in my view is that at this juncture of Canada's economic and political history, there are other and more compelling forces that will lead to an increased government involvement in all aspects of society. More importantly, this new wave of government intervention is likely to be particularly inimical to the viability and flexibility of the market economy. Therefore, the task that I have set for myself in this lecture is, first, to identify some of the factors that point to an increasing role for government and, second, to address the related issue of how this encroachment by government is likely to affect the future of the market economy.

There are three strands to my analysis. The first relates to the evolution of the perception of the state by citizens from their vantage point both as consumers and producers. These two roles will be referred to as the "domestic household" and "enterprise sector", respectively, although they are obviously not mutually exclusive. This section builds on the valuable framework developed in the early chapters of Scott Gordon's monograph [1977] where he focuses on the three primary social goods--welfare, justice, and liberty--and fashions an analysis of the manner in which they have contributed singly and together, to the growth and perception of the modern state. To these primary social goals, I would add an important fourth, the quest for economic security or protection, even though this is probably embedded somewhere in the concepts of economic welfare and social justice. It is in this drive for increased security and protection including, for example, claims for proprietary rights to the status quo, that I foresee a willingness on the part of society to accept an enhanced role for the state. 
The second part of the analysis essentially pits this securityoriented conception of society against the uncertainty and adjustment characterizing Canada's current challenges on the economic front. This confrontation bears the seeds of a substantial further intrusion of government into all facets of the economy--an intrusion that has the potential for dealing a severe blow to the market system. There is a certain irony in all this. The Keynesian revolution gave birth to macro economics and to the mushrooming of the role of the government sector. Indeed, since the government took responsibility for stabilizing economic activity at high employment this meant that a large area of economic activity became dependent upon political rather than market processes [Skidelsky, 1977, p. VII]. Now, with the fallure of macro policies on the one hand, and the evolution of rising expectations on the part of citizens in large measure facilitated by the Keynesian revolution on the other hand, government intervention is likely to increase again. The difference is, and it is a critical difference, that the new intervention will not occur in the stabllization branch, but rather in the allocation and distribution branches, to use Musgrave's phraseology [Musgrave, 1959].

In the final section, the analysis moves away from the private sectorpublic sector perspective and directs attention to government itself, or more specifically to the current intergovernmental confrontation and the impact of this on the wellbeing of the market economy. Inherent in the manner in which Canadian federalism has been developing is not only a tendency to balkanize our already small national market but a process that to an increasing degree is transferring economic decision-making from the domain of the marketplace to that of the political arena. 
To be sure, the rise of neo-conservatism as a political and social philosophy may act as a very effective brake on further government encroachment into the private sector. However, in my opinion, neo-conservatism is a movement borne out of the general malaise of recent economic history and directed principally against the growth of expenditures and taxes that characterized the Keynesian revolution, rather than a force that can be readily directed against the leading edge of the increased demands for government intervention that will arise from a preoccupation with economic security.

\section{A : The Protected Society}

Should economic security emerge as the winner, Canada could find Itself well along the path toward what I call the "protected society". I want to outline briefly the principal elements in the protected society scenario, not so much as an attempt at persuasion but rather as a backdrop which provides the motivation for much of the analysis which follows. A protected society is one in which many or most groups (from small specialinterest associations to entire provinces) have turned toward government not only to help them achieve a relative income position within society that they perceive might be unattainable without such regulation, ${ }^{1}$ but also to render them immune to the vicissitudes and discipline of the market economy. Naturally, some groups in the economy are already partially or fully under the protective umbrella of the state either as a result of conscious policy decisions (e.g., equalization payments for the have-not provinces and Indexation of income maintenance programs) or as a (unintended?) by-product of regulation. But what happens if and when more and more groups succeed in being so regulated? At this point society clearly crosses the threshold and becomes engaged in a negative sum economic game. ${ }^{2}$ Relative price signals become muted, adjustment is impeded, underemployment and 
unemployment abound and the system becomes internally driven in the sense that the response to the increasing cost and inefficiency arising from the increasing rigidity of the economic structure leads almost inevitably to even more government intervention. Within such a framework resource allocation increasingly becomes a political rather than a market phenomenon. Moreover with the decline of the market system as a coordinating institution, the regulation of social and economic activity becomes progressively more personalized and paternalistic. The logical culmination of the protected society scenario is aptly captured by Edward Gibbon's comment, albeit in a different context, on the fall of Athenian democracy: "In the end they valued security more than they valued freedom, and they lost both." [Owen and Braeutigam, 1978, p. 36].

II. The Interaction Between the Domestic and Public Households

A. The Social-Good Attributes of Consumption

Let me begin the discussion of the interaction between the domestic and public households by arguing that one reason that economists tend to over-estimate the resiliency of the market and consequently downplay the underlying drive for increased intervention relates to the very heart of the neoclassical formulation of household behavior. Subject to a budget constraint our typical consumer is assigned a utility function which essentially involves maximizing consumption over time. However, we are very reluctant to allow interpersonal comparisons to enter this utility function. In turn this implies that consumption is a private good. This is fine as long as we are talking about human "needs"--for a hungry man the satisfaction derived from a hearty meal is not going to be much affected by knowing that others may be dining at Maxim's. But in our affluent society it is more appropriate to focus on consumption as satisfying "wants" rather 
than needs and increasingly there is a "social-good" attribute associated with want satisfaction. Nothing new here. Duesenberry and Veblen before him told us all about this "Jones effect".

Complications arise, however, when this social-good aspect of want satisfaction takes on the properties of what the late Fred Hirsch (1977, p. 27) referred to as "positional goods" or, more generally, the competition by people for "place" in society. Let us take a rather extreme example of this positionalgood nature of consumption, namely that individuals want to rise in the society's relative income ladder. Immedlately one runs up against the fallacy of composition or what might be referred to as the social "paradox of thrift"-what is possible for one individual is not possible for all! Again, not too surprising, especially for those who have perused Schelling's Micromotives and Macrobehavior [19.78].

The economist's approach to this dilemma is, as Boulding has noted [1973, p. 95], to point out the inefficiency of attempting to wrestle \$1 away from one's fellow man when for the same effort one can wrestle $\$ 10$ from Nature. But this is entirely beside the point if people do have strong moral feelings about the distribution of income. For example, a widely held expectation is that the key to success in the relative income scramble is to invest in human capital. But what happens when all your peers also get a university education? The time-honored path of the acquisitive society runs you smack into the reality of the macro fallacy. Expectations are dashed, you feel that the market system let you down, so where do you turn? One obvlous answer is to turn to the state, in short to "politicize" the issue of distribution. Thus the rationale for individual maximization weakens as the importance in utility functions of these positional goods Increases . 
B. The State as the Public Household

The Incompatibility between positional expectations and the neoclassical

paradigm as a catalyst for government intervention may not be entirely convincing to economists since, as noted above, it is predicated on the harbouring of inappropriate expectations. Even state intervention cannot satisfy these expectations in their extreme form. Convert these "relative" income aspirations into "rising" income aspirations, to refer again to our simple example, and the internal conflict in the system disappears.

Yet the fact that society does harbour such expectations is symptomatic of the way in which individuals have come to view themselves within a growing capitalist society and more particularly of the way in which they have come to view the role of the state. It was not too long ago that the family was the basic social and economic unit providing not only for the basic needs, but also the educational, welfare and intergenerational requirements of its members.

However, the role of the family was transformed by the very elements that fostered the growth of the market system such as the increase in mobility, occasioned by the fall in transportation and communication costs, and the acceleration in the rate of technological change. (As an important aside, no economist wrote more profoundly on these developments than did Harold Innis.) The extended family gave way to the nuclear family and more recently to the single-parent family. In the process, altruism declined and charity became institutionalized. These developments enabled the modern family unit to become mobile, hedonistic, utility maximizers, thus conforming to the prescriptions of the neoclassical paradigm and, more importantly, adapting to the needs of a modern market economy. 
The transformation of the state was equally remarkable. In response to the loosening of traditional ties--the family, social and friendship networks, customs and traditions--the state was called upon increasingly to supplant these traditional sources of protection and security. Charity was not only institutionalized, but it was transferred "from the realm of benevolence into that of justice" and in the process the "state conferred upon its citizens the right to receive aid from society with a minimum of reference to the sentiments of compassion and benevolence which activated the older forms of charity" [Gordon, 1977, PP. 43-4]. Gordon links this development to Sir William Beveridge's famous report on the British social security system in 1942 . Referring to this report as the "Beveridge transform", he asserts that "it may turn out to be the most significant change in the socio-economic relationship of Western society since labour became a commodity that was bought and sold in the marketplace" [1977, p. 44]

Over the years, with the refinements in the principles of economic welfare and soctal justice the demands on the state transcended the domain of human needs and entered the realm of human wants. Indeed, they have now broadened into a very encompassing set of claims--social, political, environmental, etc. As Daniel Bell has remarked "the revolution of rising expectations which has been one of the chief features of western society in the past 25 years, is being transformed in a revolution of rising entitlements in the next 25 " [1977, p. 39]. Moreover, it is increasingly the case that the "satisfaction of private wants and the redress of perceived inequalities are not pursued, individually, through the market, but politically by the group, through the public household" [Be11, 1977, p. 51] . Iater in the paper, when focusing on the uncertainties associated with the current economic situation, I shall argue that one of the entitlements claimed by the citizenry is a property 
right to the status quo and that this will almost of necessity have to be pursued through the public household since it is the market that is signalling the need for abandoning the status quo.

It is important to note that this rationale for the on-going encroachment of government in the affairs of society goes well beyond the common notion that government grows because the distribution of ballots in the political market is more equal than the distribution of "dollar votes" in the marketplace. If this were all there was to it, we should have been in the "steady state", whatever it is, decades ago. This is not to say that the increased role of government is independent of the increased extension of the franchise, but rather that the more equal distribution of votes in the political system provides the mechanism whereby the changing perceptions of the role of the state on the part of citizens find their way into legislation. For example, I belleve that it is the evolution of thought pertaining to the role of the state in accommodating the goals of justice and equity, rather than competition among political parties for votes, that is tending to shift government philosophy away from guaranteeing equality of opportunity and toward guaranteeing equality of result (as reflected in such programs as Affirmative Action in the U.S.), especially since such laws tend often to discriminate against the majority of voters.

At this juncture, it seems appropriate to return to the "anti-state" sentiment raised in the opening paragraph and ask whether it has the potential to stem these rising demands for increased government intervention. There is no doubt that the apparent success of the movement will put a damper on the ability of the state to accommodate, by the expenditure route, the rising flood of special interests. Rather than competing for a share of an increasing government pie, these interest groups will be pitted against 
each other in order to gain priority for a share of a constant (or at least slower growing) pie. However, expenditures are only one method of placating special interest groups. To control expenditure growth only to find that claims on government are being satisfied via the tax-expenditure route is hardly a victory for those espousing a reduced role for government. Obviously curtailing government expenditures in combination with a cessation of borrowing from future generations would effectively limit the ability of governments to buy off these groups with direct payments. But this is clearly not the end of the matter. There still exists what Douglas Hartle [1979, p. 1] has identified as the essential, and far and away the most pervasive, function of government, namely government regulation. I believe that the real battle over the future role of government and, therefore, the future role of markets, will be fought on the regulation front. And it seems to me that the neo-conservative movement is concerned more with upfront operations of governments that can be readily tabulated in terms of expenditures and taxes than with the hidden costs of regulations of economic activity, let alone the rising claims for regulation in the environmental, moral and social spheres. Moreover, as far as government regulation is concerned, the political spectrum does not really dichotomize into two groups-one favoring more and ane favoring less regulation. Rather there exists a fascinating schizophrenia--those espousing economic liberty typically are in favour of moral and social regulation and vice versa (Be11, 1974, p. 63). 
regulation and moral liberty, decrying any government interference with individual morality, whereas typical conservatives are in favor of economic liberty and moral regulation [Be11, 1974, p. 63].

III. The Public Household and the Enterprise Sector,

If government regulation is coming to the fore as an avenue for bestowing property rights on consumer groups, its role as a device for granting protection in the enterprise sector is far greater still. However, as recently as a decade or so ago, it was not widely recognized that much of the so-called "public-interest" regulation of enterprise also embodied a significant income redistribution. This gradual revelation became popularized as Stigler's Law, namely that regulation normally tends to be in the interests of those being regulated. More recently, this approach has been superseded by what might be termed the "market" for regulation in the sense that economists now treat both the demand for and supply of regulation. 4

The demand for regulation is straightforward: As Albert Breton, one of the pioneers in this area, points out, governments have the power to reduce competition whether by tariffs, quotas, marketing boards, licensing, or similar devices and this provides a tremendous incentive for groups to organize to try to have this power used to their own advantage (1976, p. 11). Governments, for their part, are quite willing to supply this sort of regulation for several reasons, high among them being that it can be a highly effective mechanism for bloc-buying of votes. ${ }^{5}$ The overall costs and benefits of a given set of regulations pertaining, say, to implementing quotas on cheese imports, may be roughly offsetting, but the benefits are concentrated in the hands of a small, identifiable group of producers while 
the costs are widely dispersed across the consuming public. Moreover the subsidy is effectively hidden in the sense that regulation does not leave an easily identifiable and regularly published statistical trail, as would a direct subsidy. There are, of course, many other reasons why governments might want to supply regulation or, for that matter, why firms would demand regulation. But I want to return to the main thrust of the paper, namely that regulation is protection and that there exists the potential for a significant increase in regulation.

Toward this end, the aspects of regulation that are particularly relevant are not only those associated with granting an industry a valuable property right but also those that shelter it from the discipline of the market and, more generally, provide an alternative to the market as an allocative mechanfism. In many cases the two aspects will be difficult to distinguish. For example, regulation that eliminates price competition within an industry and also prevents entry not only will tilt the distribution of income toward the industry, it will also shelter the firms from market developments external to the industry. Teehnological change and innovation arising in the marketplace cannot impinge directly on behavior within the industry. But the income-distributional and market-sheltering aspects need not be coincidental. It is this latter aspect of regulation, namely the ability of regulated firms to substitute the regulatory process for the market as the allocative mechanism, that in my opinion plays a far greater role in the demand for regulation than most economists have hitherto been willing to concede.

Therefore, one of the major roles that the regulatory process can play, and one that those being regulated often want it to play, is to 
Impose due process requirements on any change in the existing set of goods, prices and market structures [Owen and Braeutigam, 1978, p. 35]. This protects expensive investments from sudden, unexpected reductions in value that might occur if these economic agents were subject to the discipline of an unfettered market. Two implications derive from this approach to regulation. First, unlike the domestic household which often aspires to proprietary claims on the status quo, regulation can provide the enterprise sector with legal rights to the status quo. Second, allocative decisions are transferred from the market sphere to the realm of the administrative process or the courts--in other words, politicized.

I recognize that this argument for protection is difficult to distinguish empirically from the more traditional argument that regulation is designed to achieve an increased return on investment through acquiring property rights. Yet in the current enthusiasm for deregulation, this distinction is frequently absent. I agree fully that regulation does typically embody one or more of the evils ascribed to it, e.g., inhibiting innovation, suppressing technical change, depressing economic growth, overinvesting in plant and equipment, tilting the income distribution in favor of the regulated, bestowing property rights. But if one of the principal goals of those seeking regulation is to acquire legal rights to the status quo, then it seems to me that one does not make too many converts by arguing for the elimination of regulation and returning to the discipline of the market, which is the very antithesis of the status quo.

Part of the problem, therefore, rests with society's perception of the market mechnaism as a ruthless, impersonal, unpredictable, and therefore, risky allocative device. Lipsey recognized this when he noted that the market is often the bearer of bad news and whereas past rulers executed messengers who brought bad news, today's rulers tend to pass laws to suspend the market's actions, in effect executing it as well [1979, p. 38]. 
Unless and until these perceptions alter and the public recognizes the vital role played by decentralized markets in coordinating production and consumption decisions, in adjusting to altered underlying conditions and in allowing more scope for the exercise of personal freedom, it is my opinion that the deregulation syndrome will not meet with much success.

\section{A. Galbraith and Regulation}

Professional purism aside, no discussion of the future of economic regulation can afford to ignore John Kenneth Galbraith's writings on the role of government in the modern capitalist society. He views what I have been referring to as the enterprise sector as a dual system. It comprises, on the one hand, the "planning system"--basically the large-scale corporations where the combination of organization and knowledge [referred to as the technostructure], enables these firms to exercise wide control over their economic environment. On the other hand, there is the market system composed of the myriad of small firms which are subordinate, Galbraith asserts, to the economic environment of which the planning sector is an Integral part. While many of us may not accept Galbraith's views of the workings of the enterprise sector, we cannot deny the irifluence he has had on public policy and, therefore, we ignore at our own peril the policy prescriptions that he draws from his analysis.

What are these policy recommendations? The most well-known to Canadians (because it was consistent with, if not the motivating force behind, the AIB and all its trappings) is Galbraith's insistence on the necessity of wage and price controls for the planning sector in order to control inflation. But I am more interested in his six recommendations for the market system, which in general amount to providing this sector with more power, i.e., with more protection. Galbraith contends first 
[1973, Ch. XXV] that small businessmen should be encouraged by government to collude in order to stabilize prices and output. Should this not be feasible, because of the "free rider" problem for example, Galbraith then calls for direct government regulation of prices and output. His third and fourth recommendations concern labour: governments should provide strong support not only for unionization of the market sector but also for an increase in the minimum wage to put market-sector workers on par with their counterparts in the planning system. The fifth recommendation is that commercial policy be utilized to increase the protection afforded to the industries in the market sector. His last recommendation comes as no surprise--the provision of a guaranteed income in the market sector as a matter of right for Individuals who cannot find employment-and there would be a lot of them if his other proposals were implemented!

In effect, Galbraith is saying that the planning system is here to stay and that in order to provide the same degree of protection and security for the market sector, it is necessary to make the latter more like the former. In short, Galbraith embraces the protected society and the consequent politicizing of the allocative and distributive process. To continue along the Galbraithian line, it seems to me that what firms can gain by regulation, whether such regulation is sought out or bestowed, is to transfer themselves from the market system to the planning system (where I am now using Galbraith's concept of the planning system in the very general sense of acquiring some sort of property right). Yet much of economic analysis (both theoretical and empirical) of regulation focuses on the efficiency loss of such action and, as a group, economists might be viewed as attempting to argue that it is preferable to keep these industries in the market sector. But it seems to me that this approach will meet with 
success only if we go the next step and devote a much larger portion of our analysis and research toward exposing the planning sector (again loosely defined) to the discipline of the market. Let me take an example close to home. Most of us belong to the university or government world. And those of us who entered universities or government during the expansionary years of the 1960 's are surely collecting rents relative to those who entered a decade later--rents that because of the customs and traditions (i.e., regulations) of our institutions are likely to remain. Put another way, custom and tradition have become increasingly important in determining pay scales. Marginal productivity retains its major significance in influencing levels of employment at these pay scales, not the pay scales themselves as anybody who has attempted to introduce even a reasonable "merit" component into a university salary settlement knows only too well. For how long, then, in good conscience, can we turn the powerful tools of economic analysis toward the unregulated sectors and proclaim that in the name of economic efficiency their livelihood should be governed by the discipline of the market? As long as some economic agents are able to fall under the protective umbrella of government regulation in the sense of having valuable property rights bestowed on them, what canon of justice or equity can we fall back upon that would suggest that others be excluded? It seems to me, therefore, that we have to turn our attention increasingly toward facilitating the degree to which the market governs those sectors that currently benefit from protective regulation before we can with any force argue that regulation should not increase in the "market sector". Unfortunately, resorting to economic efficiency as the rationale for increasing the wage and price flexibility in the sheltered 
sectors is probably not going to carry the day. Efficiency, as Irving Kristol notes [1978, p. 83], "is not a moral virtue and by itself never legitimizes anything". Rather, we are going to have to fall back on some combination of primary social goals such as justice, equity and liberty as legitimizing forces. For example, the institution of tenure not only bestows a property right but also inhibits access by others to positions for which they might be more qualified than the current holders. Thus the argument against regulations like tenure can indeed be made on the basis of justice or equity and liberty, with efficiency as a positive byproduct.

There is, however, another aspect of the protected society which Galbraith's approach may help shed light upon, namely the tendency for regulation or protection to beget further regulation and protection. Consider Canada's generous unemployment insurance program, for example. There are no doubt many ways to rationalize its existence. One of them, I would suggest, ought to include the fact that by offering compensation to those who are victims of protected markets elsewhere in the system government facilitates the preservation of these sinecures. The pressure for wage flexibility in protected spheres would be enhanced substantially were there no unemployment insurance. It is clearly in the interest of the current beneficiaries of these shelters to ensure that government steps in to accommodate the victims of their actions. Therefore, if governments are unwilling to introduce more flexibility into currently regulated markets they are inevitably going to be faced with the necessity of introducing more protection elsewhere in the system.

In summary, then, even though Galbraith's analysis may not rest well with mainstream economists $I$ am afraid that, short of important structural changes in the currently protected sector, he probably has a fairly accurate bead on the likely future developments in capitalist economies. 
IV. Protectionism and the Realities of the $80^{\prime} \mathrm{s}$

Thus far the focus has been on the various factors relating both to the domestic household and the enterprise sector that might give rise to increased demands for government intervention. In this section I want to confront those tendencies with current economic realities and more particularly with the evident failure of macroeconomic policies over the past decade. The combination of rising expectations and/or entitlements on the one hand and faltering economic performance on the other bears the potential for a signiflcant rise in the trend towards protectionism. ${ }^{6}$ There are three aspects of the present economic reality that merit attention--inflation, the Internal adjustment occasioned by rising energy prices, and the prospect of several years of $10 \mathrm{w}$ or zero real growth. Although they are not independent of one another, the kinds of demands for increased-intervention they elicit are sufficiently different to justify treating them in isolation, albeit very briefly.

\section{A: Inflation}

It is probably not an understatement that, until recently, an influential group within our profession seriously undervalued the problem of inflation. We focussed on the consequences of a fully anticipated inflation and argued that the cost of inflation was essentially to be found in the effects of a predictable tax on money balances. To be sure this cost could be high. But this framework of analysis effectively ignored the role of a stable monetary system as one of society's major social and economic coordinating and communicating organisms. ${ }^{7}$ Correspondingly, it underestimated substantially 
the degree to which various institutions, let alone individuals, could adapt to instability in the underlying monetary order..

In a most insightful article, Axel Leijonhufud [1977] argues that Inflation will alter the pattern of socio-economic activities in two broad areas. First of all, in Inflationary periods, belng efficient and competitive at the production and distribution of "real" goods and services becomes less important to the outcome of socio-economic activity. Forecasting inflation and coping with its consequences become more important and people will reallocate their efforts and ingenuity accordingly [p. 280]. In other words, the productivity of careful allocative calculations is eroded by inflation, partly because relative price information arising from the market has a high noise/signal ratio and partly because the expected returns from such an activity are swamped by the benefits of correctly forecasting inflation. Leijonhufvud's second point is that this will lead to the situation where "people will rely relatively less on private contracts and relatively more on political compacts in trying to ensure for themselves a reliable frame for their economic lives" [p. 281]. In short, there will exist a tendency for the representative individual and firm to turn away from the market sphere (which, in effect, has been rendered less efficient as a signalling device) and towards the political sphere in order to attempt to ensure a more predictable environment. I think that this is a major part of the reason why the corporate sector was not openly hostile to the AIB, much to the puzzlement of the majority of the free-market economists.

There is a second and related consequence of inflation, namely that it may erode the moral underpinning of the market system. Governor Bouey, In his 1976 Annual Report alluded to this when he noted that "experience with inflation undermines the confidence of people in the fairness of economic 
processes" [p. 8]. Each of us can probably cite particular instances where peoples' experiences with the effects of inflation have led them to question seriously the fairness of the market as an allocative device. The episode that epitomizes this for me occurred in early 1974 when newspapers across the nation were heralding the advent of double-digit inflation. Yet the Bank Rate remained at $7.25 \%$ Individuals began to scramble in order to hedge themselves against the ravages of inflation and, not surprisingly, the most obvious and convenient hedge was the housing market. As a result, housing prices jumped. precipitately in the first quarter of 1974. Dreams were shattered, substantial wealth transfers occurred, and the market as an allocative mechansim was called into question.

Societal consensus in favour of a market economy no doubt reflects, among other things, that free markets have proven themselves in terms of generating high average incomes and that the resulting income distribution reflects, to a large degree, relative social products. The impact of inflation, however, is to render this latter aspect of the market system very suspect because the distribution of income becomes progressively more difficult to rationalize in terms of social productivities. When this occurs, the perception of the price system no longer is compatible with socially approved goals and the inevitable temptation is to resort to greater and greater intervention [Krueger, 1974, p. 302]. There is no question in my mind but that experience with inflation has convinced a goodly number of Canadians that polftical rather than market allocative mechanisms are preferable across an increasingly broad range of goods and services. 


\section{B : Energy and Ad justment}

No one likes to have the rug pulled out from under his or her economic future. But that is exactly what happens to many people when markets are allowed to work in the face of major shocks to the system such as the one occasioned by the recent and rapid escalation in the world energy prices. In this age of rising entitlements there is, as noted above, a very strong current that asserts proprietary rights to the status quo. And having implicitly accepted this principle over the past, in terms of legislation such as equalization payments and quotas for textiles, government has little choice but to recognize, in part at least, the validity of these claims. In this, we are not alone. Across the Western world the spectrum of protectionism is growing as country after country seeks to pass off the costs of the OPEC cartel to others. Yet Canada has to contend not only with this international problem but also with the East-West internal adjustment. The issue is not really whether government is going to intervene--it has intervened and will continue to do so. Rather it seems to me the critical issue is the form that the intervention is going to take. Essentially, we can choose policies that will accomodate the adjustment that is signalled by the rapid increase in the terms of trade for energy or we can attempt to thwart or frustrate this adjustment by the imposition of what I have elsewhere referred to as "gap-closing" policies [1978]. The former are clearly to be preferred in terms of the scope they allow for the functioning of markets. Yet the latter have the appeal of minimizing the immediate-term adjustment and they normally carry the day even though the longer-term consequences of these gap-closing policies are generally to exacerbate and rigidify the original problem. 
The plight of Chrysler Canada and Windsor workers generally is a case in point. That the government was going to take some action was surely not in doubt given the high level of unemployment in the motor city. However, I fail to see how bailing out a declining firm in a declining Industry constitutes anything but a gap-closing measure. Indeed, it seems to me that Canada has already started on the path toward "Maritimization" of Ontario as far as the transfer system is concerned.

There is another implication for the functioning of markets that accompanies an adjustment process as severe as that now confronting Canada. This is the bellef that somewhere in the system there must be a great spring of undeserved income that can be tapped by political means and diverted to sustaining private incomes and existing claims on society's production. In the minds of many Canadians the obvious repositories of undeserved income are the oil companies, particularly foreign-owned oil companies. However, the confiscation of these "windfall profits", not all of which would qualify as economic rents, will lead inevitably to a more politically determined allocation of resources in these sectors. That is not simply due to the fact that the elimination of windfall profits effectively emasculates the market's signaling system. It also results because, as lipsey points out, the "predictable success of [these] controls in frustrating the free-market adjustments will be taken as evidence that the free market doesn't work and this will justify further centrally administered price controls, quotas, rationing schemes and compulsory orders to alter consumption and production habits." [1979, p. 37.] 
C: In the Shadow of the Stationary State ${ }^{8}$

As a result of the combination, among other things, of inflation and rising energy prices the Western world is facing a period, perhaps a prolonged period, of slow growth or "slowth" to use the current jargon. One reason for this relates to the fact that capital is going to have to deepen considerably in order to maintain the current mix of output. For example, the capital requirements for one barrel of oil per day from a syncrude-type plant run to nearly $\$ 20,000$ in 1980 prices [Beigie, 1979, p. 38]. Moreover, the cost of the capital investment required for all kinds of pollution control equipment as laid down, for example, by the EPA in the United States and comparable agencies in Canada is very substantial. What this means is that "total" factor productivity is in all probability going to rise at a very much slower pace than over the recent past. Part of this reduction reflects a measurement error in the sense that past factor productivity was overestimated because natural resource Inputs were treated as "free", with their average productivity normally attributed to capital. In the case of non-renewable resources this leads to a drop over time in measured factor productivity as the low-cost deposits are used up. Part also should be viewed as a statistical illusion in the sense that the traditional definition of output neglects environmental quality, workIng conditions, health levels, and the like [Beigie, 1979, p. 40]. But this social-indicator approach to the definition of output will provide little solace to people whose expectations have been formed on the basis of the current output mix.

It is undoubtedly misleading to identify slowth with the stationary state in the sense that the current period will certainly not be characterised by the routinization and dullness that Adam Smith hailed as the hallmark of 
the stationary state. Nonetheless the adjustment to slow growth can be nearly as difficult as the adjustment to a stationary society. Growth is the solvent which dissolves much of the potential conflict of our increasingly redistributive society: the poor can become richer without the rich becoming poorer. Unfortunately, with slow growth it becomes progessively more difficult to escape from the rigours of scarcity. In this environment the demands for protection and rent seeking (or what Douglas Hartle calls the "new entrepreneurship") will have a tendency to rise to the fore since it may no longer be possible for groups to get out of Nature what they can squeeze out of their fellow man. And with this rise in the relative return to exploitation, the fate of the market may suffer further as government steps in as the distributive and, most likely as well, the allocative referee. Consider a concrete example, Canadians have yet to come to grips with just how and when we will effect the substantial redistribution toward the coming bulge in the pensioned sector. Yet to contemplate this transfer under conditions of low or zero growth without infringing on the advantages of the market in terms of its scope for individual freedom and social adaptability is, I should think a concern of the first magnitude. We may or may not share Boulding's view [1973, p. 95] that stationary states typically degenerate into mafia-type societies in which government is primarily an instrument for redistributing income toward the powerful and away from the weak. But I do think that he is correct in asserting that the problem of bullding political and constitutional defenses against exploitation while at the same time maintaining the advantages of market-type societies will emerge as a major challenge as long as our economy remains in the shadow of the stationary state. 
V. Federalism and the Market System 9

In his Presidential Address to this Association, John Dales put forth the proposition that 'government is our most precious scarce resource, and probably one of those special, common pool resources" [1975, p. 502]• Therefore, Dales argued, access to government should be made difficult and the cost of political participation kept high in order to prevent government from transforming itself into a common property and succumbing to the "tragedy of the commons" [p. 502]. For present purposes, and from an economist's vantage point as well I should think, this is a most instructive analogy. Government does preside over a vast pool of potential property rights, dispensing them in pursuit of its own ends as well as in response both to society's prevailing attitudes toward basic goals such as justice, equality and 1 iberty and to the myriad demands from special-interest groups. In some sense, the efficiency gains arising from a well-functioning market system are embodied in the "rent" to society that arises from government maintaining restricted access to these potential property rights. Privatizing these rights directs benefits toward particular sectors of society and the resulting efficiency loss can be viewed as rent diminution arising from overuse of the common property resource.

One problem with this analogy, and indeed with the entire analysis to this point, is that government is viewed as a single entity. The viability of the market system has been cast in terms of the interaction between the public sector and the private sector. ${ }^{10}$ But what about the interaction within 
the public sector itself? The reality of the Canadian version of federalism

is that there are precious few ground rules that allocate, or more importantly prevent the allocation of, this pool of potential property rights among governments. In the final analysis the outcome of this inter-governmental struggle will surely play a major role in determining the degree toward which Canada moves along the route towards the protected society.

On the surface, the economic theory of federalism would appear to be particularly appealing to market-oriented economists. Provinces are viewed as providing alternative bundles of public services and citizens can choose their province according to preferences for these various bundles. This "voting by foot" aspect introduces into the government sphere some of the flexibility and competition that characterizes the operations of decentralized markets. Yet the practical reality of federalism is that provinces, too, can and should be viewed as special-interest groups. And it may not be too farfetched to vlew federalism itself as a regulatory process, the beneficiaries of which on many occasions, as Stigler's Law would suggest, are the provinces-as provinces and not as the collection of individuals that comprise them. For example, it has always struck me as intriguing that we have a comprehensive negative income tax scheme for provinces (the equalization program) but lack a comprehensive negative income tax for individual Canadians. More importantly, in the scramble over the division of powers and in the beggar-thy-neighbour federalism that is emerging (only in part a result of the stagflation and adjustment problems defined above), there looms the distinct possibility that the viability of the market system in this country will be dealt a severe blow and that the political sphere will increasingly influence resource allocation. 
One of the problem areas is, as Safarian [1974] has explained, that the B.N.A. Act does not provide the necessary constitutional guarantees for a common market in goods, labour and capital across provinces. As a result, impediments to mobility abound, even to the point where qualified observers have claimed that in some respects the European Common Market has fewer internal barriers to trade than Canada has. And even where the B.N.A. Act would prevent provinces from passing legislation in restraint of trade, the provinces have been able to entice Ottawa into enacting enabling legislation to make such Intervention constitutionally legal. Agricultural marketing boards exemplify this best. As Safarian [1974, pp. 49-50] points out, attempts by provincial marketing boards to levy a fee on one group of producers in order to increase the return to another group have generally been considered by the courts to be an indirect tax. Accordingly, the granting of such power to a marketing board by a provincial legislature was declared to be ultra vires. But in response to the courts' decisions in this area, the federal Agricultural Products Marketing Act was amended in 1957 so that the Governor in Council could authorize provincial boards to engage in these activities. By September 1, 1970, 59 provincial marketing boards had their provincial powers extended to interprovincial and export trade:

Obviously, the barriers to interprovincial trade extend well beyond the domain of agricultural products. Since they are rather well documented [e.g., Ontario Economic Council, 1978], there is little to be accomplished by reiterating the litany. However it is probably instructive to note that of late there has been a relatively new development--a rapid proliferation of barriers to the interprovincial mobility of capital. The attempt by British Columbia to prevent an interprovincial takeover of Macmillan-Bloedel is likely the most visible, but probably not the most significant example. 
Quebec has initiated what in effect amounts to an RRSP for individuals who purchase new equity issues of quebec-based companies and many provinces are about to follow suit. In addition, there are the various provincial heritage trusts that are designed to channel capital in specific directions. The Impact of these impediments has the potential of going well beyond balkanizing our already small domestic market and severely distorting the allocation of resources. In my view, this proces has politicized (perhaps "provincialized" is a better word) the allocation process to such a degree that on the economic front we are close to degenerating into what, for want of a better phrase, I refer to as mercantalistic provincialism.

A second general problem relates to the extensive degree to which one level of government is able to pass off the costs of its policies to the other level. This is due in large measure to the overlapping of jurisdictions relating to the distribution of powers between Ottawa and the provinces. No doubt some 'trading off' would exist under virtually any power division, but some of the implications of the current arrangements appear particularly serious. = For example, Quebec has the highest minimum wage on the continent, let alone in Canada. One of the reasons it is able to maintain this is that much of the costs of such a policy are borne by other Canadians. Ottawa steps in with UIC payments and equalization payments as well as one-half of the costs of welfare payments that arise from the high minimum wage. Moreover, because of its high unemployment, Quebec can then lobby (successfully) for such things as import quotas for its textile industry. Another example, not quite so serious but nonetheless instructive in terms of how far things can be carried, is the 1977 Nova Scotla Job Corps program which, as far as I can make out, employed 1,000 people for a 12 week period--just long enough for them to qualify for federal UIC benefits for the remaining 40 weeks of the year and, therefore, take them off the provincial welfare roles. Without trying to wade into the delicate area of the distribution of powers, it 
seems to me that every effort must be made to ensure that those jurisdictions that have the right to legislate in a given area must also be the ones to bear the economic costs of this legislation. If they are able to pass the costs along to another level of government or to other Canadians, not only will distortions creep in but there will be a tendency, as I have indicated elsewhere [1978], for provinces to make "economic prisoners" of some of their lessadvantaged citizens.

The direction the federation ought to be moving is one which "emphasizes the rights of Canadians, individually and in voluntary associations, against all levels of government" [Safarian, 1979, p. 23]. Indeed, these basic rights--a "code of economic conduct" to be adhered to by all governments, as It were--should be entrenched in the Constitution, preferably as part of the much-talked-about "Bill of Rights". At a minimum this should incorporate a guarantee of an internal common market in goods, services, labour and capital.

There are several factors which reduce the likelihood of such a constitutional reform. First of all, when Ottawa and the provinces talk about the division of powers there is precious Iittle reference to any third parties who might also be privy to some of the spoils. From a historical perspective this is more than a trifle disconcerting since I have always viewed the role of constitutions, from the Magna Carta onward, in terms of protecting rights and liberties of citizens against the power of the state. Secondly, entrenching such rights into the constitution would mean that the Supreme Court would be called upon to play a much greater role as arbiter than it has heretofore been. It has not been our tradition, recently at least, to place great reliance on the courts for ironing out federal-provincial conflicts. 
Rather, Canada has engaged in what has come to be known as "executive federalism"--conferences of executives from the federal and provincial governments. Fast approaching one thousand such meetings annually this may well be Canada's "contribution to the art of federalism" [Safarian, 1979, p. 24]. Nonetheless, however valuable executive federalism may be to lending the needed flexibility to the B.N.A. Act in the political sphere, this "third level of government" has not had a positive influence in the economic sphere. Just as the regulatory process is usurping the role of the market place in the private sector, executive federalism is usurping the role of the courts in the public sector. And without the courts to protect basic rights of private sector economic agents, it is entirely possible that executive federalism will, ironically, deplete the very pool of potential property rights that John Dales felt should be protected from the insatiable claims of the private sector! Since the institution of executive federalism is serving increasingly to downplay the role of Parliament at both the federal and provincial levels, the real issue may well be the "tragedy of the Commons".

\section{Conclusion}

This, then, is my assessment of the various tendencies that make the protected society scenario, and its accompanying politicization of economic life, more plausible than might appear at first blush. I have no grandiose recommendations or proposals that would make the future, at least as I see it, more rosy. However, there are a few suggestions that derive from the analysis.

First, there is really very little respect for, and perhaps more important very little understanding of, the market mechanism in the real world whether 1 t be in the public or private sector. In turn this suggests that 
those of us who believe that the laws of economics cannot be ignored without creating serious economic, social and political repercussions--1et alone the trade-off between economic security and individual liberty--must take this message beyond the classroom. The second suggestion runs in the other direction. I think that it is becoming increasingly important to bring into the classroom a much better appreciation and analysis of the institutional framework of modern economies. In the Canadian context this would include such institutions as the regulatory process, the Supreme Court, the governmental decision process, and federalism itself. Thirdly, If my analysis is correct and if citizens are going to insist on more protection, then it should not be difficult to design programs that protect Individuals without damaging the efficiency of markets.

What currently passes for protection-related legislation is often not at all based on insurance principles, and not cost-efficient. And where there is an income distributional aspect to the program it is generally the case that these policies are not effective in helping the desired beneficiaries.

Finally society's perception of the role of the market, like the market Itself, is anything but static. Thus it would appear essential to gain an overview of the march of political, social, and economic events in order to maintain a proper perspective both as to how the market system is likely to evolve and as to the sorts of policy measures that are likely to be appropriate at any given time. For example, it accomplishes little to argue against any and all intervention when it is clear to everybody that the government is going to intervene. It is far better, in situations like this to get behind the type of intervention that will leave the market most viable and free from political influence. On this need for perspective, the philosopher of summer, Yogi Berra, put it rather aptly: "If you don't know where your're going, you may end up somewhere else." 


\section{Footnotes}

* Charting unknown territory is always trying. My way has been made considerably easier by the generosity of colleagues both at Western and elsewhere. My greatest debt is to Ron Wintrobe for his continuing interest in and contributions to the development of the ideas in the paper. It is a pleasure to also acknowledge the valuable comments I have received from Carl Beigie, Kathleen Day, Joel Fried, John Palmer, Dick Lipsey, Glenn MacDonald, Grant Reuber, Steve Margolis, Ed Safarian, Dick Shroyer, James Stewart and Ron Wirick. Most of these individuals will probably be relieved to note that I accept full responsibility for what follows.

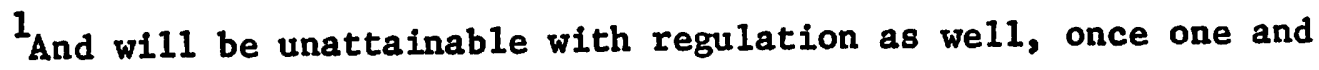
all get into the game. This is a classic case of the signalling problem. I could be convinced not to seek regulation as long as I knew everyone else would refrain as well. Not being able to be assured of this, it is in my own interest to seek protection and to seek it early rather than late.

2 This assumes a closed economy since it is possible for some regulation (e.g., the optimum tariff) to generate gains at the expense of foreigners. 3 However, positional-related expectations are not the only way to frustrate the system--zero growth will do just as well, as will be outlined below.

4 Much of the analysis that follows will focus on the negative aspects of regulation even though a very substantial body of regulation is positive, in the sense of accommodating the operations of markets. To take a few simple examples, weight-and-measure regulations surely facilitate the circulation of goods, traffic lights facilitate the ciculation of vehicles, and regulations that prevent the imposition of residency requirements promote the mobility of labour. 
${ }^{5}$ Note that this bloc-buying of votes as a rationale for intervention Is quite distinct from the notion advanced earlier that government intervention in the marketplace is responding to the fact that the distribution of votes is more equal than the distribution of income. Indeed, intelligent buying of voting blocs would focus on marginal groups (marginal in terms of their voting patterns) regardless of their existing income shares.

${ }^{6}$ Ron Wirick [1979] has made the important point that this may well be a vicious circle. Intervention at the micro level, triggered by unsatisfactory macro performance, may seriously restrict the functioning of macro policies, thereby leading to further intervention.

7Obviously, this does not apply to the "Austrian" approach to money. See Laidler and Rowe [1980].

${ }^{8}$ Some of the ideas in this section, and indeed some of the phrases, are from an article of the same title by Boulding [1973].

${ }^{9}$ Jean-Luc Migu'e (1979) has recently documented and analyzed what he refers to as "nationalist" or "protectionist" policies in Canada. Our treatment will be far more selective.

${ }^{10}$ Not much attention in this paper has been directed to the impact on the market economy arising from the growing size of government as measured, say, by the percentage of total GNP flowing through the government sector. While this is a critical issue, it is also one that has been treated at length elsewhere and, accordingly, has essentially been ignored in this analysis. 


\section{$\underline{\text { References }}$}

Adams, Michael, J. (1980) "A Canada of Cross Currents," in Report, Montreal: Association for Report on Confederation.

Bank of Canada (1976) Annual Report.

Beigle, Car1 (1979) Inflation is a Social Malady (Montreal: C. D. Howe Research Institute).

Be11, Daniel (1974) "The Public Household or 'Fiscal Sociology' and the Liberal Society," The Public Interest, pp. 29-68.

Boulding, K. E. (1973) "In the Shadow of the Stationary State," in M. Olson and H. H. Landsberg eds., The No-Growth Society (Toronto: George J. McLeod Ltd.). Breton, Albert (1976) The Regulation of Private Economic Activity (Montreal:

C. D. Howe Research Institute).

Courchene, Thomas J. (1978) "Avenues of Regional Adjustment: The Transfer System and Regional Disparities," in M. Walker, ed., Canadian Confederation at the Crossroads (Vancouver: The Fraser Institute), pp. 143-86.

Dales, John H. (1975) "Beyond the Marketplace," Canadian Journal of Economics VIII, No. 4, PP. 483-503.

Friedman, Milton (1977) Friedman on Galbraith (Vancouver: The Fraser Institute). Galbraith, J. K. (1973) Economics and the Public Purpose (Scarborough: The New American Library of Canada).

Gordon, H. Scott (1977) "The Demand and Supply of Government: What we Want and What we Get," Economic Council of Canada Discussion Paper No. 79. Hartle, Douglas C. (1979) Public Policy Decision Making and Regulation (Montreal: Institute for Research on Public Policy).

Hirsch, Fred (1976) Social Limits to Growth (Cambridge: Harvard University Press). 
Innie, Harold, A. (1946) Political Economy in the Modern State (Toronto: The Ryerson Press).

Kristol, Irving (1978) Two Cheers for Capitalism (Scarborough: New American Library).

Krueger, Anne, 0. (1976) "The Political Economy of Rent Seeking," The American Economic Review, Pp. 291-303.

Laidler, D. E. W. and Nicholas Rowe (1980), "Georg Simmel's Philosophy of Money: A Review Article for Economists," Journal of Economic Literature Vol. XVIII, PP. 97-105.

Leifonhufvud, Axe1 (1977) "Costs and Consequences of Inflation," in G. C. Harcourt, ed., The Microeconomic Foundations of Macroeconomics (London: The Macmillan Pres8), Pp. 265-312.

Lipsey, R, (1979) "An Economist Looks at the Future of the Market Economy," paper presented to the XV Annual Nobel Conference on the Future of the Market Economy, Gustavus Adolphus College, St. Peter, Minnesota.

Migue, Jean-Luc (1979) Nationalist Policies in Canada: An Economic Approach. Accent quebec Series (Montrea1: C. D. Howe Research Institute).

Musgrave, Richard, A. (1959) The Theory of Public Finance (Toronto: McGraw-H11).

Ontario Economic Council (1978) Government Regulation: Issues and Alternatives, 1978, (Toronto: Ontario Economic Council).

Owen, Bruce and R. Braeutigam (1978) The Regulation Game (Cambridge: Ballinger Publishing Company).

Safarian, A. E. (1974) Canadian Federalism and Economic Integration, Constitutional Study prepared for the Government of Canada (Ottawa: Information Canada). Safarian, A. E. (1979) "Ten Markets or One? Regional Barriers to Economic Activity in Canada," mimeo. 
Schelling, Thomas, C. (1978) Micromotives and Macrobehavior (New York: Norton). Skidelsky, Robert (1977) ed. The End of the Keynesian Era (New York: Holmes and Meier Publishers Inc.)

Wirick, Ronald (1979) "Structural Constraints on Canadian Stabilization Policy: The Inflation Adjustment Problem," in Wirick, R. and Purvis, D. (eds.) Issues in Canadian Public Policy II (Queen's University: Institute for Economic Research). 